\title{
FERTILITAS DAN RELASI GENDER DI DESA NEGLASARI, KABUPATEN BOGOR
}

\author{
Dian Ekowati ${ }^{*}$, Ekawati Sri Wahyuni, dan Said Rusli \\ Departemen Sains Komunikasi dan Pengembangan Masyarakat, Fakultas Ekologis Manusia, IPB \\ *)Email : dee.ekowati@gmail.com
}

\begin{abstract}
Fertility is often seen on the figures and biological sides. Seeing fertility goes beyond both of these will be useful to explore the wishes of each actor, how they relate to each other and to the community, and how the values and aspects of sociological and psychological that is attached in such activities. The study explored how the relationship between gender relations and fertility work; especially because until now there is no generic theory agreed to this issue. This study used qualitative methods to explore and gain an understanding of how women give birth as related parties with the other actors. The framework of this study were made by utilizing research - research that has been done before, namely the concept of female autonomy (Mason and Smith , 2003) and the concept of the determinant (Bongaarts, 1978). The concept is referred to aspects of women's autonomy is the power of women to make household economic decisions, the power of women to make decisions about family size, women freedom of movement, individual attitudes toward gender attitude of the community, and the movement of women in decision-making ( Mason and Smith, 2003. Determinants required for connecting between socio - economic variables culture with fertility because after all, there are facts that can not be denied that fertility is the result of biological activity. The results showed that although the values at the community level suggested to have the number of children that a lot, to a certain extent, the women in the study area can control the number of children they have. This control works through Desired fertility and the determinants, namely : the use of contraception and delay the age of marriage is influenced by women's autonomy and power as proposed by Mason and Smith ( 2003). Women's autonomy and power in question is the power of women in economic decision-making, decision-making power of women in family size, their physical freedom of movement, the size of the gender attitudes at the community level, and their space in household decisionmaking. The conclusion of this study indicate that in the study area, the use of contraception is more influential in affecting fertility than the actual delay marriage age.
\end{abstract}

Keywords : Gender Relationships, Fertility, Aspects of Women's Autonomy and Power, Desired Fertility, Actual Fertility, Reuters Determinants

\section{PENDAHULUAN}

Alih-alih sekedar hasil dari sebuah kegiatan biologis, anak dalam keluarga adalah hasil dari proses pengambilan keputusan yang melibatkan keinginankeinginan, motivasi dan relasi antar aktor yang terlibat di dalamnya. Ragam dimensi dalam kelahiran anaktelah menarik perhatian para ahli tidak hanya dari kalangan biologi, tetapi juga dari latar belakang demografi, sosiologi, ekonomi, psikologi dan antropologi (Robinson dan Harbinson, 1983).

Kelahiran seorang anak dimulai dengan sebuah proses pengambilan keputusan dalam keluarga ${ }^{1}$ mengenai

\footnotetext{
${ }^{1}$ Hal ini merujuk pada kondisi yang umum ditemukan di budaya Indonesia, di mana anak berada dalam wilayah keputusan keluarga yang terdiri atas suami dan istri, bukan oleh pasangan yang tidak menikah dan tidak membentuk keluarga.
}

jumlah anak yang diinginkan (desired fertility $)^{2}$.Pengambilan keputusan dalam keluarga mencakup pengambilan keputusan oleh istri atau suami sendiri, bersama setara, dan atau bersama dengan suami atau istri dominan (Sajogyo, 1983).Lebih jauh dalam hubungannya dengan relasi kuasa, Wolf dalam Visanathan et al. 1997 dalam Savitri, 2007 menyatakan bahwa hanya sedikit rumah tangga yang ditemukan bekerja di bawah suasana demokratis, sehingga strategi rumah tangga seringkali melibatkan relasi kekuasaan, dominasi dan subordinasi.Selain proses pengambilan keputusan di dalam keluarga, kelahiran seorang anak juga mencakup proses di luar keluarga, di mana kelembagaan

\footnotetext{
${ }^{2}$ Merujuk pada istilah yang digunakan Easterlin (1975), yakni jumlah anak yang diinginkan dalam keluarga.
} 
komunitas, agama, adat, budaya, dan pemerintah memiliki pengaruh. ${ }^{3}$

Setelah desired fertility diputuskan, proses yang selanjutnya terjadi adalah apakah jumlah anak tersebut dapat diakomodasi oleh kelembagaan KB (Keluarga Berencana) yang memberikan pelayanan kontrasepsi untuk pembatasan kelahiran dan kesehatan reproduksi. Semakin mudah dan murah akses keluarga terhadap sarana dan prasarana kontrasepsi maka akan semakin mungkin jumlah anak yang dilahirkan (actual fertility) mendekati jumlah anak yang diinginkan (desired fertility). Sebaliknya, jika akses keluarga terhadap sarana dan prasarana kontrasepsi semakin sulit dan mahal, maka jumlah anak yang dilahirkan (actual fertility) akan semakin mendekati jumlah anak potensial dan jumlah anak lahir yang tidak diinginkan (direncanakan) pun akan semakin semakin besar (Easterlin, 1975).

Pentingnya studi mengenai desired fertilitydisampaikan oleh Pritchett (1994) dalam Aggarwal (2006) bahwa 90 persen perbedaan actual fertility antar negara dapat diterangkan dengan desired fertility. Sebagaimana telah disinggung di atas, keputusan ini melalui sebuah proses yang mencerminkan hubungan antar anggota keluarga; terutama hubungan antara suami dan istri, dengan pengaruh dari luar keluarga. Hubungan antar suami istri tercermin dalam relasi gender dalam keluarga yang merupakan konstruksi dari nilai-nilai dan norma sosial budaya pada level komunitas. Secara umum ditemukan bahwa saat perbedaan peran gender antar perempuan dan laki-laki semakin sedikit, perempuan memperoleh status dan kuasa di dalam masyarakat dan mulai memiliki kontrol atas aspek reproduksinya (Riley, 1997). Lebih lanjut, Riley (1997) menyebutkan bahwa saat perempuan memiliki otonomi lebih besar, kesehatan ibu dan anak semakin meningkat, fertilitas dan kematian anak menurun dan pertumbuhan penduduk akan lebih lambat.

Masalah kemudian muncul saat para peneliti menemukan bahwa status atau otonomi perempuan sebagai variabel untuk mengukur relasi gender bukanlah hal yang sederhana. Kompleksnya hal ini tercermin dari berbagai peneliti yang memaknai status atau otonomi perempuan yang berhubungan dengan fertilitas dengan cara yang berbeda. Beberapa peneliti melihat status atau otonomi perempuan dari kualitas individual, beberapa contohnya adalah Kabir, et al. (tidak ada tahun), Akmam (2002) dan Hakim et al. (2003).

Kabir, et al. (tidak ada tahun) memaknai status perempuan dari pendidikan perempuan, pekerjaan perempuan dan perannya dalam diskusi keluarga berencana. Kabir et al. (tidak ada tahun) dalam penelitiannya yang menggunakan data Survey Demografi dan Kesehatan Bangladesh 1999-2000 menemukan bahwa terdapat tiga indikator dalam status perempuan yakni; pendidikan, pekerjaan dan diskusi perencanaan keluarga

\footnotetext{
${ }^{3}$ Proses dalam keluarga ini dalam periode tertentu pernah hampir tidak berlaku di Indonesia, saat pemerintah Orde Baru mengambil alih hak keluarga untuk memutuskan jumlah anak yang dilahirkan dan melaksanakannya dengan cara yang koersif.
}

yang memiliki pengaruh penting dalam meningkatkan penggunaan kontrasepsi dan penurunan fertilitas.

Sementara itu, masih di Bangladesh, Akmam (2002) menemukan bahwa pendidikan perempuanlahyang terutama memiliki pengaruh besar terhadap fertilitas. Itu umumnya bekerja mempengaruhi fertilitas melalui keinginan atas jumlah anak, jumlah anak yang dimiliki dan biaya kontrasepsi. Lebih lanjut, Akmam (2002) mengemukakan bahwa pengaruh terbesar dari pendidikan muncul saat level pendidikan perempuan adalah di level menengah; sementara sedikit pendidikan dasar sepertinya tidak memiliki pengaruh signifikan terhadap fertilitas. Dalam kesimpulannya, Akmam (2002) menyebutkan bahwa setelah melewati batas pendidikan menengah tersebut, semakin tinggi pendidikan perempuan akan mengurangi angka kelahiran.

Berbeda dengan Kabir dan Akmam, Hakim et al. (2003) yang menggunakan data Survey Fertilitas dan Keluarga Berencana Pakistan Tahun 1996-1997 menyimpulkan bahwa terdapat tiga indikator utama otonomi perempuan yang memiliki pengaruh signifikan terhadap penggunaan kontrasepsi, yakni; mobilitas spasial, pengambilan keputusan mengenai perawatan anak dan pengambilan keputusan mengenai pembelian makanan. Lebih lanjut, ia menyatakan bahwa semakin tinggi kontrol perempuan dalam pengambilan keputusan mengenai pembelian makanan memiliki pengaruh paling signifikan dalam menurunkan angka kelahiran dibanding indikator yang lain. Tiga indikator yang digunakan oleh Hakim et al. (2003) tersebut sejalan dengan indikator yang digunakan oleh Mason dan Smith (1999) di lima negara Asia.

Namun, pada kesimpulan laporannya, Mason dan Smith (1999) menekankan bahwa indikator di level individu tersebut memiliki pengaruh yang jauh lebih lemah terhadap fertilitas dibandingkan indikator di level komunitas. Meski demikian, indikator individu tetap penting untuk dilihat karena terdapat semacam spekulasi bahwa jika sistem sosial-budaya menyarankan seklusi dan domestifikasi pada perempuan (sebagaimana ditemukan dalam komunitas patriarki); keluarga dengan kondisi sosial ekonomi yang lebih rendah akan memiliki relasi gender yang lebih setara, vice versa (Mason dan Smith, 1999 dan Hull, 1975). Mason dan Smith (2003) kemudian juga menekankan pentingnya untuk secara bersama-sama mengubah norma gender di level komunitas dan meningkatkan aspek-aspek individual perempuan (meningkatkan usia kawin, pendidikan dan kesempatan kerja) dalam upaya pemberdayaan perempuan untuk meningkatkan statusnya dalam relasi gender.

Dalam upayanya memahami indikator-indikator keterberdayaan perempuan, Mason dan Smith berdasarkan hasil penelitiannya di 56 komunitas di lima negara Asia (Pakistan, India, Malaysia, Thailand, danFilipina)merumuskan lima aspek, yakni:

1. Kuasa perempuan dalam pembuatan keputusan ekonomi - apakah mereka berpartisipasi dalam keputusan-keputusan ekonomi yang besar dalam keluarga dan apakah mereka memiliki kebebasan 
dalam membuat keputusan ekonomi yang lebih kecil tanpa harus bertanya ke anggota keluarga yang lain?

2. Kuasa perempuan dalam pembuatan keputusan terkait ukuran keluarga - apakah mereka berpartisipasi atau ikut mengontrol keputusan mengenai jumlah anak yang ingin dimiliki?

3. Kebebasan perempuan untuk melakukan mobilitas fisik - dapatkah mereka mengunjungi tempat-tempat misalnya pasar lokal, layanan kesehatan atau taman di luar desa tanpa harus bertanya terlebih dahulu kepada anggota keluarga yang lain?

4. Kontrol suami terhadap istri melalui intimidasi dan paksaan - apakah mereka takut untuk tidak setuju dengan pendapat suami karena khawatir suami akan marah, dan apakah suami pernah memukul mereka?

5. Selain keempat aspek tersebut, Mason dan Smith (2003) juga mengusulkan aspek kelima dalam menelusuri hubungan relasi gender dan fertilitas, yakni sikap gender di level komunitas yang dipahami oleh individu.

Sebelumnya, Mason dan Smith (1999) telah menguji aspek otonomi perempuan tersebut secara kuantitatif dengan menggunakan data survey 56 komunitas pada lima negara Asia, yakni Pakistan (Punjab), India (Uttar Pradesh dan Tamil Nadu), Malaysia, Thailand dan Filipina ${ }^{4}$. Mereka menemukan bahwa terdapat pola hubungan yang cukup konsisten di level makro bahwa pada komunitas-komunitas di mana perempuan memiliki kekuasaan pengambilan keputusan lebih besar dan kebebasan bergerak, mereka memiliki actual fertility yang lebih rendah, keinginan yang lebih rendah untuk menambah anak, dan penggunaan kontrasepsi yang lebih tinggi. Temuan Mason dan Smith (1999) ini sejalan dengan temuan Hakim et al. (2003) di Pakistan. Hakim et al. (2003) menemukan bahwa di Pakistan, indikator otonomi perempuan sebagaimana yang digunakan oleh Mason dan Smith (1999) berkorelasi positif dengan penggunaan kontrasepsi. Lebih lanjut, Hakim et al. (2003) menemukan bahwa aspek otonomi perempuan yang terkuat pengaruhnya terhadap penggunaan kontrasepsi adalah pengambilan keputusan ekonomi rumah tangga dalam hal pembelian makanan.

Meski demikian, baik Mason dan Smith (1999) maupun Hakim et al. (2003) setuju bahwa bagaimana cara otonomi perempuan mempengaruhi fertilitas belum dapat dipastikan. Hakim et al. (2003) menyatakan bahwa kepastian ini belum dapat ditemukan karena penelitian kualitatif yang menggali mengenai hubungan antara kedua variabel ini belum dilakukan. Penelitian kualitatif diperlukan untuk mengetahui makna di balik otonomi dan kuasa perempuan yang akhirnya dapat mempengaruhi actual fertilitynya. Pada komunitas-komunitas yang berbeda, akan terdapat norma-norma komunitas yang mengatur relasi gender secara berbeda. Meski demikian,

\footnotetext{
${ }^{4}$ Pada penelitian ini, Mason dan Smith (1999) merumuskan aspek otonomi perempuan ke dalam 3 indikator, yakni pengambilan keputusan ekonomi, pengambilan keputusan terkait jumlah anak dan mobilitas perempuan. Pada tulisan merekaselanjutnya
}

keunikan antar individu dalam sebuah komunitas memungkinkan adanya variasi relasi gender antar individu-individu di dalamnya.

\section{Proximate determinant(Variabel Antara) Fertilitas}

Relasi gender adalah variabel sosial budaya, sementara fertilitas hanya dapat dihasilkan melalui sebuah proses biologis. Oleh karena itu, upaya untuk menghubungkan langsung variabel gender dengan fertilitas seringkali menemukan inkonsistensi. Bongaarts (1978) menyebutkan bahwa cara ini bermasalah dalam aplikasinya; karena sering ditemukan bahwa ada perbedaan besar dan arah antar kedua variabel dalam setting tempat dan waktu yang berbeda. Kompleksitas ini dimungkinkan karena fertilitas adalah variabel yang bersifat biologis, sementara gender adalah variabel sosial budaya sehingga tidak dapat dihubungkan secara langsung melainkan harus melalui variabel antara.

Untuk mengatasi hal ini, Bongaarts (1978) telah mengusulkan variabel antara (proximate determinant) fertilitas yang ia definisikan sebagai faktor-faktor biologis dan perilaku melalui mana variabel sosial ekonomi, budaya dan lingkungan mempengaruhi fertilitas. Ide Bongaarts ini merujuk pada ide awal yang dilontarkan oleh Davis dan Blake pada tahun 1956 yang mengusulkan 11 variabel. Bongaarts pada awalnya mengusulkan delapan variabel, tetapi kemudian pada kesimpulannya terhadap data nasional beberapa negara maju dan berkembang dengan metode kuantitatif, Bongaarts menemukan bahwa hanya usia menikah, kontrasepsi, aborsi yang disengaja dan infekundabilitas karena laktasi yang menjadi proximate determinant utama (Bongaarts 1978).

Beberapa penelitian kemudian mencoba menggali fenomena fertilitas dengan memanfaatkan proximate determinant yang ditawarkan Bongaarts (Baschieri dan Hinde, 2007; Guengant, tidak ada tahun; Moses dan Kayizzi, 2007). Ketiganya melakukan penelitian dalam konteks makro dan menemukan bahwa proximate determinant Bongaart dapat menjelaskan penurunan atau kenaikan fertilitas dengan baik.

\section{RUMUSAN MASALAH}

Hubungan antara relasi gender dan fertilitas adalah hal yang ditelusuri lebih jauh dalam penelitian ini, meskipun sampai saat ini belum ada kesepakatan mengenai indikator relasi gender yang memiliki pengaruh terhadap fertilitas. Penelitian ini dilakukan pada sebuah komunitas desa dengan konteks Islam konservatif ${ }^{5}$. Data

\footnotetext{
5 Definisi Islam konservatif merujuk pada Islam yang menekankan pada penafsiran doktrin keagamaan secara ketat dan dogmatis, tanpa membuka peluang bagi penafsiran baru sesuai konteks saat ini. Ciri umum aliran ini adalah penekanan ketaatan kepada buku-buku klasik tentang penafsiran Al Quran dan Hadits yang mulai beredar sejak Abad ke 16 (Di Indonesia umum disebut dengan istilah kitab kuning). Kitab ini umumnya dikarang oleh para ulama lelaki. Kritik terhadap pemaknaan ketat kitab kuning dari kalangan feminis terkait penafsiran ayatayat Al Quran dan Hadits yang bias lelaki karena kepentingan politik, konteks budaya dan sosial ekonomi yang menjadi setting
} 
dan temuan di komunitas dan negara yang mayoritas penduduknya muslim konservatif menunjukkan bahwa perempuan memiliki otonomi yang relatif terbatas (Mason et al. 1998 dalam Mason dan Smith 1999). Data lain (United Nations Statistics Division, 2011) juga menunjukkan bahwa angka pertumbuhan penduduk di negara-negara muslim lebih tinggi dibandingkan pada negara-negara yang mayoritas penduduknya bukan penganut muslim.

Sejalan dengan hal tersebut, Mason et al. (1998), dalam Mason dan Smith (1999) menyebutkan bahwa di mana perempuan memiliki gerak yang terbatas, maka akses terhadap kontrasepsi juga terbatas. Fenomena ini dapat dipahami dengan melihat doktrin-doktrin dalam Islam konservatif. Salah satu doktrin Islam konservatif yang terpenting adalah mengenai stereotype yang melekatkan perempuan hanya di ranah domesti, dan kritik terhadap pembatasan peran perempuan di ranah publik seringkali diartikan sebagai penyerangan terhadap agama Islam (Basya, 2003). Pandangan ini seringpula dibarengi dengan pandangan bahwa dalam agama Islam, lelaki adalah lebih berharga dibandingkan perempuan, dan perempuan seolah-olah kemudian menjadi manusia kelas dua (Nataprawira dan Pribadi, 2003). Berdasarkan temuan-temuan tersebut, dapat diharapkan bahwa di sebuah komunitas tradisional yang kental dengan budaya Islam konservatif yang patriarki maka para perempuannya akan memiliki otonomi dan kebebasan yang terbatas serta fertilitas yang tinggi.

Desa Neglasari, tempat penelitian ini dilakukan, adalah sebuah desa di Provinsi Jawa Barat berbatasan dengan Banten. Di desa ini terdapat sembilan pesantren tradisional ${ }^{6}$, sehingga konteks Islam konservatifnya masih sangat terasa. Setiap pesantren dipimpin oleh seorang Kiai, yang juga dianggap sebagai tokoh informal di desa, meski pengaruhnya sudah mengalami penurunan dari generasi ke generasi. Pengaruh Kiai antara lain ditunjukkan dengan kemampuannya memobilisasi santri untuk suatu kepentingan tertentu ${ }^{7}$. Sejalan dengan kegiatan pesantren oleh para santri, kegiatan pengajian adalah kegiatan rutin yang dilakukan oleh sebagian besar warga. Studi di desa ini kemudian menjadi menarik karena dalam lingkungan yang kental dengan konteks Islam konservatif dan budaya Sunda yang patriarki, para perempuan di desa ini kemudian memiliki kesadaran mengenai pentingnya pembatasan kelahiran, dan lalu

dari kitab kuning tersebut. Istilah Islam konservatif sering pula disamakan dengan Islam fundamentalis.

${ }^{6}$ Pesantren tradisional di sini didefinisikan sebagai sebuah pesantren yang fokus pada pendidikan keagamaan, dengan sumber kitab suci dan kitab-kitab kuning. Dalam pesantren ini, pelajaran sesuai kurikulum sekolah tidak didapatkan. Demi memperoleh pendidikan umum, beberapa siswa memilih untuk bersekolah umum di pagi sampai siang hari dan baru "nyantri" setelah pulang sekolah dan sekaligus menginap di pesantren.

${ }^{7}$ Salah satu contoh mobilisasi santri adalah saat santri menggerebek penyuluhan Keluarga Berencana dan Kontrasepsi oleh penyuluh kecamatan di balai desa karena kiai menganggap kegiatan tersebut bertentangan dengan nilai-nilai agama. Peristiwa ini terjadi pada Bulan September 2011, saat kegiatan P2WKSS berjalan di desa studi. mampu beradaptasi dalam lingkup relasi gendernya untuk mempengaruhi fertilitas mereka.

Berdasarkan uraian di atas, maka peneliti merumuskan masalah sebagai berikut:

1. Bagaimana kondisi fertilitas di desa studi?

2. Bagaimana karakteristik relasi gender pada keluarga-keluarga di desa studi?

3. Bagaimana relasi gender bekerja dalam mempengaruhi fertilitas di desa studi?

\section{METODE PENELITIAN}

Penelitian ini memanfaatkan penggunaan metode kualitatif meski biasanya dalam ilmu kependudukan metode kuantitatif dengan survey telah lebihumum digunakan karena sifatnya yang banyak bergerak di aras makro. Namun, akhir-akhir ini metode kualitatif telah pula banyak dimanfaatkan dalam disiplin ilmu ini. Pilihan pendekatan untuk penelitian ini sejalan dengan Randall dan Koppenhaver (2004) yang menyebutkan bahwa alasan utama diversifikasi metode ini adalah untuk meningkatkan pemahaman atas perilaku dan fenomena dalam kependudukan, alasan lain adalah untuk meningkatkan kualitas data survey, untuk mengumpulkan data mengenai aktivitas ilegal atau sembunyi-sembunyi atau untuk mengumpulkan data dari sub-grup tertentu, misalnya orang tua yang sulit disurvey.

Lebih lanjut, mereka juga menyebutkan bahwa pendekatan ini terutama telah banyak digunakan untuk studi-studi mengenai persepsi, kegelisahan, dan sikap mengenai suatu subyek, misal fertilitas, keluarga berencana, kesehatan reproduksi, penyakit yang menular secara seksual - Sexually Transmitted Diseases (STD) dan penurunan kekebalan tubuh akibat virus - Human Immuno defficiency Virus (HIV). Penggunaan pendekatan kualitatif dalam isu-isu tersebut terutama dikarenakan pengambilan keputusan tentang kegiatan reproduktif memiliki implikasi kebijakan yang penting dan karena itu memerlukan pemahaman yang mendalam. Selain itu, isuisu tersebut adalah isu sensitif yang terkait perilaku seksual, yang tidak akan mudah digali melalui survey (Randall dan Koppenhaver, 2004).

Pemilihan responden dilakukan dengan pertimbangan demi mencapai tujuan penelitian, yakni demi memperoleh karakteristik relasi gender yang berbeda dan perbedaan fertilitas. Responden yang dipilih adalah pasangan-pasangan dengan usia perempuan antara 45-59 tahun, sudah menikah dan memiliki anak kandung. Pertimbangan pemilihan responden dengan rentang usia 45-59 tahun adalah:

1. Pada umur tersebut, para perempuan sudah menyelesaikan masa reproduksinya, sehingga fertilitas antar responden dapat diperbandingkan.

2. Dengan usia tersebut, responden mengalami proses program Keluarga Berencana yang diinisiasi oleh pemerintah pada tahun 1969/1970, sejak gencargencarnya sampai mengalami kelemahan saat otonomi daerah.

3. Responden sudah mengalami berbagai kondisi relasi gender dalam pernikahan mereka. 
Aspek kehati-hatian untuk memilah responden perempuan yang sudah mengalami pernikahan lebih dari satu kali juga diterapkan, untuk menghindari kerancuan dalam analisis data relasi gender dan jumlah anak. Responden yang diwawancara adalah istri dan suami dalam wawancara yang terpisah. Suami juga diwawancara demi memperoleh gambaran relasi gender yang dipersepsikan oleh masing-masing pihak demi ketebalan informasi.

Selain responden, wawancara juga dilakukan terhadap informan yang dipilih dengan teknik bola salju untuk memperoleh pemahaman atas isu tertentu yang memerlukan pemahaman di aras komunitas; misalnya nilai-nilai budaya yang dianut mengenai relasi suami istri, jumlah anak, dan nilai anak. Selain responden dari golongan umur 45-59 tahun, dilaksanakan pula wawancara pada responden dan informan dari pasangan yang lebih muda, yakni di bawah 45 tahun. Tujuan dari hal ini adalah sebagai perbandingan informasi dan pengkayaan data. Data yang diperoleh dari responden dan informan yang lebih muda juga bermanfaat untuk mengetahui kecenderungan perbedaan dan perubahan relasi gender dan fertilitas antar generasi di desa studi.

\section{HASIL DAN PEMBAHASAN}

\section{Fertilitas di Desa Neglasari}

Data mengenai kelahiran anak belum tercatat di desa. Berdasarkan pengamatan dan wawancara dengan para informan, jumlah anak pada pasangan lebih muda yang belum mempunyai cucu (atau berusia sekitar 20-40 tahun) adalah lebih sedikit dibandingkan jumlah anak pada pasangan yang lebih tua, yang sudah mempunyai cucu (atau kurang lebih berusia di atas 40 tahun). Meski pasangan yang lebih muda masih memungkinkan untuk menambah jumlah anak karena masih dalam masa reproduktif, tetapi dengan memperhitungkan penambahan jumlah anak yang mungkin terjadi sampai masa reproduksinya berakhir; yakni dengan melihat jarak kelahiran dan desired fertility, jumlah anak pada pasangan ini akan tetap lebih sedikit.

Jumlah anak pada pasangan yang telah memiliki cucu pada umumnya lebih besar dari lima orang anak hidup. Bukanlah hal yang aneh untuk menemukan perempuan yang melahirkan lebih dari sepuluh anak pada perempuan dengan rentang usia tersebut. Pada saat pasangan ini melalui masa reproduksinya, kematian anak saat lahir, bayi maupun balita adalah hal yang relatif wajar. Pada setiap keluarga, kematian anak umumnya terjadi antara satu sampai tiga kali. Sementara saat ini, jumlah anak pada pasangan yang belum bercucu (usia anak pada umumnya di bawah 20 tahun) paling banyak adalah lima orang. Kematian anak adalah hal yang masih ada tetapi jarang ditemui saat ini.

Tabel 1 menampilkan rangkuman data fertilitas yang dimiliki oleh 41 responden perempuan yang berusia antara 35 - 59 tahun. ${ }^{8}$ Data tersebut sejalan dengan temuan

Tabel 1 Fertilitas Responden Desa Neglasari, Kabupaten Bogor, Tahun 2011

\begin{tabular}{|c|c|c|c|c|c|}
\hline & $\begin{array}{c}\text { Rata-rata } \\
\text { kali } \\
\text { menikah }\end{array}$ & $\begin{array}{c}\text { Rata-rata } \\
\text { usia } \\
\text { perkawinan }\end{array}$ & $\begin{array}{c}\text { Rata-rata } \\
\text { jumlah } \\
\text { anak } \\
\text { lahir } \\
\text { hidup }\end{array}$ & $\begin{array}{c}\text { Rata-rata } \\
\text { jumlah } \\
\text { anak } \\
\text { meninggal } \\
\text { pada waktu } \\
\text { bayi* }\end{array}$ & $\begin{array}{c}\text { Rata-rata } \\
\text { jumlah } \\
\text { anak } \\
\text { hidup }\end{array}$ \\
\hline $35-44$ & 1.27 & 18.73 & 3.64 & 0.18 & 3.54 \\
\hline $45-59$ & 1.48 & 32.86 & 6.73 & 0.70 & 6.03 \\
\hline Total & 1.38 & 25.79 & 5.18 & 0.44 & 4.78 \\
\hline
\end{tabular}

* Bayi yang dimaksud di sini adalah rentang usia $0-12$ bulan.

Sumber: Olahan data primer

dari hasil wawancara dan pengamatan yang menunjukkan bahwa para perempuan yang berusia antara 35-44 tahun memiliki rata-rata kali menikah, jumlah anak yang dilahirkan dan jumlah anak meninggal yang lebih sedikit dibandingkan dengan para perempuan dari kategori usia 45-59 tahun. Argumen mengenai lebih sedikitnya jumlah anak pada responden perempuan dengan usia 35-44 tahun memang dapat dibantah dengan kemungkinan bahwa jumlah anak mereka akan bertambah karena masa reproduksi mereka belum berakhir. Namun, terdapat fakta yang menunjukkan bahwa saat masa reproduksi perempuan tersebut berakhir, mereka tetap akan memiliki jumlah anak yang lebih sedikit. Fakta yang dirujuk adalah selisih usia antara anak yang dilahirkan dan desired fertilitydari kutipan hasil wawancara berikut:

"Anak saya sudah 4, sementara ini saya tidak ingin menambah anak lagi, tetapi jika misalnya Allah ngasih ya tidak akan menolak". (Ibu E, 40 tahun, 3 anak, peserta KB implan)

Beberapa responden lain juga menyatakan hal yang sama bahwa "Jika Allah ngasih tidak akan menolak", mereka semuaadalah peserta KB aktif. Dari hal tersebut mereka terlihat bahwa mereka sudah tidak ingin menambah jumlah anak, tetapi enggan menyatakannya secara eksplisit. Hal tersebut menunjukkan bahwa sudah terdapat penurunan fertilitas di desa studi, meski penurunannya masih jauh dari penurunan fertilitas yang dicapai oleh Provinsi Jawa Barat, Pulau Jawa dan Indonesia (IDHS 2007). ${ }^{9}$

Mengenai jarak kelahiran antar anak, hasil pengamatan dan wawancara menunjukkan bahwa pada perempuan usia 45 tahun ke atas, jarak kelahiran anak umumnya relatif singkat, berkisar antara 2-3 tahun, sementara jarak kelahiran anak pada perempuan yang berusia 44 tahun ke bawah umumnya berkisar antara 3-6

${ }^{8}$ Pemilahan menggunakan usia 45 tahun sebagai batasan karena usia ini dianggap sebagai batasan usia perempuan untuk mulai mengalami menopause.

${ }^{9}$ Penurunan fertilitas di Desa Neglasari merujuk pada angka rata-rata jumlah anak lahir hidup dan desired fertility yang mereka miliki (desired fertility juga dipertimbangkan bagi responden yang masih pada usia reproduksi), sementara penurunan fertilitas di Provinsi Jawa Barat, Pulau Jawa dan Indonesia merujuk pada data AFT. 
tahun. Hal ini juga tampak dari hasil wawancara dengan responden usia 35 tahun sebagai berikut:

"Jumlah anak sih sedikasihnya sama Yang Kuasa, tetapi jangan sampai terlalu dekat (jarak kelahirannya). Kalau bisa minimal jaraknya 5 tahun.” (Ibu M, 35 tahun, anak 3)

Selain itu, rendahnya tingkat partisipasi perempuan usia 45 tahun ke atas pada program keluarga berencana juga memungkinkan mereka untuk memiliki jumlah anak sesuai jumlah anak potensial. ${ }^{10}$ Penjabaran lebih terinci mengenai partisipasi responden pada program keluarga berencana disampaikan pada sub bab berikutnya.

Tabel 1 juga menunjukkan relatif tingginya pengalaman kematian bayi yang dialami oleh para perempuan di Desa Neglasari. Meskipun angka tersebut telah menurun pada para perempuan pada kategori usia lebih rendah, angka 0,18 tetaplah angka yang tinggi karena ini berarti bahwa ada 1 kematian bayi pada setiap 5-6 orang bayi. Kematian bayi umumnya disebabkan oleh suhu badan yang panas dan demam.

\section{Aspek Otonomi dan Kuasa Perempuan}

Aspek relasi gender dalam keputusan terkait fertilitas yang dibahas dalam tulisan ini adalah otonomi dan kuasa perempuan yang terdiri dari lima aspek (Mason dan Smith, 2003), yakni kuasa perempuan dalam pengambilan keputusan ekonomi rumah tangga, kuasa perempuan dalam pengambilan keputusan tentang ukuran keluarga, kebebasan dalam bergerak, sikap gender di level komunitas yang dipahami oleh individu dan kontrol koersif interpersonal.

Pada penelitian ini, kontrol koersif interpersonal diistilahkan dengan ruang gerak perempuan dalam pengambilan keputusan. Istilah yang dipilih memiliki arti yang identik dengan istilah kontrol koersif interpersonal (interpersonal coercive control) sebagaimana yang diusulkan oleh Mason dan Smith (2003), tetapi istilah ruang gerak perempuan dalam pengambilan keputusan dianggap peneliti lebih sesuai dengan tujuan penelitian yang memiliki perhatian pada ruang-ruang di mana perempuan mampu memiliki akses dan kontrol sehingga mampu bernegosiasi dengan suaminya.

\section{Kuasa Perempuan dalam Pengambilan Keputusan Ekonomi Rumah Tanggadan Fertilitas Aktual}

Temuan di lapangan menunjukkan bahwa perempuan-perempuan dengan kontrol yang lebih besar terhadap keputusan ekonomi rumah tangga berpengaruh pada kemampuannya untuk mengalokasikan anggaran bagi pembelian alat kontrasepsi. Namun sebagaimana disampaikan di atas bahwa tidak semua perempuan dengan kontrol ekonomi setara memiliki desired fertility yang sedikit, maka tidak semua pula menginginkan pembatasan kelahiran. Kesimpulan yang dapat ditarik adalah bahwa saat perempuan dengan kontrol ekonomi setara menginginkan pembatasan kelahiran, maka ia dapat mengambil keputusan untuk mengalokasikan anggaran bagi biaya kontrasepsi. Sementara perempuan tanpa atau

\footnotetext{
${ }^{10}$ Jumlah anak potensial merujuk pada istilah Easterlin (1975).
}

sedikit kontrol terhadap keputusan ekonomi, meskipun ia menginginkan pembatasan kelahiran, ia akan sulit mengakses kontrasepsi.

Namun, ada pula faktor lain yang harus diingat, terdapat responden yang memiliki kontrol ekonomi setara (Ibu J, 47 tahun), tetapi situasi ekonomi rumah tangganya terlalu miskin, sehingga meski ia yang memutuskan pengeluaran rumah tangga, ia tidak mampu mengalokasikan untuk pembelian kontrasepsi. Walaupun saat itu dia merasa membutuhkan karena ia sempat merasa anaknya sudah terlalu banyak, saat ia memiliki anak kedelapan. Responden tersebut menyatakan bahwa saat ada uang yang tersisa, dan itu sangat jarang terjadi, ia akan mengalokasikan untuk membeli susu bagi cucunya. Dia juga menyatakan bahwa meskipun jumlah anak adalah keputusan Tuhan, dia tidak menginginkan anak perempuannya memiliki anak sebanyak yang dia miliki ( 9 orang hidup) karena dia sendiri merasakan betapa repotnya mengurus anak sebanyak itu dan dia juga mengkhawatirkan masa depan setiap cucunya yang lahir.

\section{Kuasa Perempuan dalam Pengambilan Keputusan tentang Ukuran Keluargadan Fertilitas Aktual}

Para perempuan responden yang sudah menyelesaikan masa reproduksinya memang memiliki anak yang relatif banyak (rata-rata 6,73 anak lahir per responden), hal ini disebabkan oleh dua hal yang berbeda. Pertama karena suami tidak mengizinkan istri menggunakan kontrasepsi, dan kedua karena keputusan istri sendiri untuk menginginkan anak banyak dan tidak ingin menggunakan kontrasepsi. Meski sama-sama menghasilkan jumlah anak yang relatif banyak, kedua hal tersebut sangat berbeda dari sudut pandang relasi gender. Pada kasus yang pertama, dapat diartikan bahwa istri memiliki kuasa yang rendah dalam pengambilan keputusan keluarga, sementara pada kasus yang kedua, istri memiliki kuasa yang tinggi dalam pengambilan keputusan ukuran keluarga.

Hal yang berbeda ditemukan pada pasangan yang lebih muda yang memiliki desired fertility yang cukup jelas dan dalam jumlah yang lebih sedikit dibandingkan anak yang dimiliki oleh orangtuanya. Pada pasangan dengan desired fertility yang jelas ini, kuasa perempuan yang lebih banyak pada pengambilan keputusan mengenai ukuran keluarga akan membawa kepada actual fertility yang lebih sedikit.

Kuasa perempuan dalam keputusan ukuran keluarga akan berpengaruh terhadap penggunaan kontrasepsi. Seorang perempuan yang memiliki kuasa dalam keputusan keluarga, akan mampu mengutarakan ide mengenai desired fertilitynyadan kemudian mampu untuk melakukan pembatasan kelahiran di saat ia merasa sudah memerlukannya. Sementara seorang perempuan tanpa kuasa dalam keputusan ukuran keluarga hanya akan menuruti keinginan suami tentang jumlah anak. Si perempuan ini juga tidak mampu untuk menegosiasikan penggunaan kontrasepsi dengan suami sehingga pada beberapa kasus ditemukan perempuan-perempuan dengan actual fertility yang tinggi karena tidak diizinkan oleh 
sang suami untuk menggunakan kontrasepsi karena suami menginginkan anak banyak.

\section{Kebebasan dalam Bergerak dan Fertilitas Aktual}

Dalam hubungannya dengan actual

fertility, kebebasan dalam bergerak berpengaruh melalui proximate determinant usia kawin dan penggunaan kontrasepsi. Sebagaimana dibahas dalam pembahasan sebelumnya, kebebasan dalam bergerak dipilah menjadi kebebasan dalam bergerak sebelum dan setelah menikah.

Temuan di lapangan menunjukkan bahwa perempuan-perempuan yang memiliki ruang gerak cukup luas sebelum menikah umumnya memiliki usia kawin yang lebih tua sehingga mempengaruhi jumlah anak yang mereka miliki. Umumnya mereka menikah di atas usia 20 tahun. Perempuan-perempuan ini, karena alasan menyelesaikan sekolah atau bekerja di kota lain memiliki kegiatan lain sehingga tidak serta merta merasa "harus" menikah saat sudah 17 tahun sebagaimana perempuan lain yang tidak memiliki aktivitas pada usia mudanya. Ketidakharusan ini mungkin juga muncul karena mereka tidak tinggal di desa selama masa sekolah atau masa kerjanya, hanya pulang setiap akhir minggu, sehingga mereka tidak merasakan langsung gunjingan dari warga lain. Wawancara dengan informan menunjukkan hal ini.

"Adik saya baru nikah di usia 26 tahun, baru saja nikah kemarin, tapi dia memang tidak tinggal di sini. Kerja di Jakarta, jadi tidak pusing sama omongan orang. Kalau tinggal di sini mungkin sudah gak kuat denger omongan orang. Saya aja yang kakaknya suka risih kalau ada yang nanyain. Sekarang juga habis nikah dia langsung pergi lagi, tinggal di dekat pasar Ciampea, nemenin suaminya jualan di sana." (Ibu S, 35 tahun)

Selain kebebasan bergerak saat sebelum menikah, kebebasan bergerak juga dilihat pada respondenresponden setelah menikah. Jika responden-responden yang relatif bebas bergerak saat ini telah memiliki kebebasan sebelum menikah, cerita yang muncul adalah identik dengan pembahasan di atas. Maka terdapat pembahasan lain bagi responden yang sebelum menikah tidak memiliki kebebasan tetapi kemudian memiliki kebebasan bergerak setelah menikah. Bagi para responden ini, mereka menikah pada usia muda, namun kemudian memiliki ide lain untuk anak-anak yang saat ini mereka miliki. Hal ini nampak pada petikan wawancara berikut.

"Saya sudah ngalamin sendiri Mbak, nikah di usia muda, saya dijodohkan dan dinikahkan langsung setelah lulus SMA dengan lelaki pilihan orangtua saya. Saya nantinya tidak akan ngelakuin itu ke anak saya, biar dia cari pengalaman hidup dulu sebelum nikah. Saya sekarang memang lebih bebas ke mana-mana dibanding dulu saat masih sama orangtua, tapi tetap beda rasanya kalau ada anak di rumah yang mesti diurus." (Ibu R, 35 tahun, seorang guru honorer untuk Pendidikan Anak Usia Dini dan SD di desa)

Dari pernyataan tersebut terlihat bahwa berdasarkan pengalamannya sendiri, dia merasakan bahwa saat ini perempuan seharusnya lebih bebas dalam mengatur keputusan-keputusan dalam kehidupannya, apalagi terkait pernikahan. Apa yang ia nyatakan sebagai pengalaman hidup adalah bersekolah atau bekerja sehingga sang anak mampu memiliki kehidupan yang lebih baik dibandingkan dia. Upaya pencarian "pengalaman hidup" ini nantinya akan menjadi penunda usia perkawinan sehingga sang anak nantinya tidak akan menikah pada usia yang terlalu muda.

Dalam kaitannya dengan penggunaan kontrasepsi, perempuan yang lebih bebas bergerak lebih mampu mengakses layanan bidan dan puskesmas demi memperoleh informasi dan layanan kontrasepsi. Transfer informasi ini berguna sehingga para perempuan memiliki kemampuan untuk mengambil keputusan terkait desired fertilitynya. Mereka mampu menyebutkan dengan jelas jumlah anak yang mereka inginkan. Hal ini dimungkinkan karena perempuan dengan kebebasan bergerak memiliki akses untuk melakukan pertukaran informasi dengan pihak-pihak luar, sehingga membentuk pandangan baru bagi mereka setelah melihat situasi luar. Sementara perempuan-perempuan dengan kebebasan bergerak yang terbatas umumnya menyatakan rencana tentang jumlah anak sebagai "rencana Tuhan".

Selain itu, dengan kebebasannya dalam bergerak, para perempuan tersebut setelah memutuskan jumlah anak yang diinginkannya akan mampu mengakses layanan kontrasepsi dengan lebih mudah dibandingkan perempuan lain yang memiliki keterbatasan dalam bergerak. Mereka akan lebih mudah untuk mengambil keputusan pergi ke puskesmas untuk mengakses layanan kontrasepsi yang mereka butuhkan. Di desa studi, diketahui bahwa jumlah anak lahir pada perempuan yang bebas bergerak adalah lebih sedikit dibandingkan para perempuan yang pergerakannya lebih terbatas.

\section{Sikap Gender di Level Komunitas yang Dipahami oleh Individu dan Fertilitas Aktual}

Dalam kaitannya dengan fertilitas aktual, sikap gender di level komunitas yang dipahami oleh individu bekerja mempengaruhi fertilitas melalui proximate determinan usia kawin dan penggunaan kontrasepsi. Beberapa responden perempuan berusia muda, 17 tahun dan 19 tahun menyatakan bahwa memang sudah seharusnya perempuan yang sudah matang untuk segera menikah. Responden pertama belum menikah, dan saat ini sedang bersekolah si sebuah pesantren di luar desa. Menurutnya, ia satu tahun lagi sudah senior (tingkat akhir) dan tinggal menunggu seorang laki-laki baik untuk melamarnya, lulus pesantren berarti pula menikah. Berdasarkan pemahamannya, ada peraturan tidak tertulis di dalam pesantren bahwa seorang santriwati senior dapat "diminta" untuk menjadi istri santri lain atau orang luar dengan seizin kiainya. Namun, aturan tersebut tidak memaksa si santriwati untuk selalu mengiyakan. Kutipan tersebut adalah hasil wawancara dengan responden.

"Saya sebentar lagi di tingkat akhir Teh, santri senior sudah boleh diminta orang untuk dijadikan istri. Gak harus santri, orang luar juga boleh, tapi harus izin Kiai. Saya ya akan lihat-lihat, tapi 
kalau Kiai dan Apa (Bapak) sudah setuju ya buat apa saya menolak." (A, 17 tahun)

Sementara itu responden kedua saat ini berusia 19 tahun, sudah menikah pada usia 17 tahun dan baru saja melahirkan anak pertamanya pada Bulan November 2011. Peneliti memiliki kesempatan untuk mengunjunginya sebelum dan setelah melahirkan. Pada masa sebelum melahirkan, sang calon ibu tinggal di rumah mertuanya, sementara sang suami bekerja di Jakarta dan mengunjunginya tiap 1 atau 2 minggu sekali. Saat peneliti menanyakan tentang usia pernikahan di desa studi, berikut adalah tanggapannya.

"Di desa ini, memang kalau sudah 17 tahun sudah pantas menikah Teh, malah kalau lewat nanti dibilang perawan tua." (N, 19 tahun)

$\mathrm{N}$ adalah penduduk asli desa dan hanya bersekolah sampai SMP. Setelah menikah, ia tinggal di rumah mertuanya yang hanya berjarak 20 meter dari rumahnya. Setelah masa melahirkan, ia kembali ke rumah orangtuanya dan diurus oleh sang ibu. Mertua sesekali mendatanginya, sementara sang suami hanya pulang selama 3 hari, satu hari sebelum dan sesudah melahirkan. $\mathrm{N}$ menyatakan bahwa ia belum tahu kapan waktu pasti untuk kembali ke rumah mertuanya. $\mathrm{N}$ tidak pernah bekerja setelah lulus SMP, ia terus tinggal di desa sejak lahir sampai saat ini. Sampai sekarang, menemukan N-N lain di desa bukanlah hal yang terlalu sulit meski sudah berkurang dibandingkan masa-masa generasi sebelumnya.

Selain pemahaman gender yang dimiliki oleh individu itu sendiri, pemahaman gender yang dimiliki oleh orangtua juga berpengaruh terhadap usia kawin sang anak. Para orangtua yang menganggap bahwa perempuan harus segera menikah pada usia muda untuk menghindari julukan perawan tua akan mendorong anaknya untuk menikah muda, bahkan beberapa menjodohkannya. Peneliti melihat bahwa pemahaman gender yang dimiliki oleh orangtua terkait dengan pertukaran informasi yang salah satunya ia peroleh dengan kebebasannya dalam bergerak.

Hal ini tampak pada seorang responden perempuan berusia 47 tahun yang memiliki kebebasan bergerak yang relatif tinggi dibandingkan responden lain. Saat ini ia memiliki anak-anak perempuan yang sedang bersekolah di akademi kebidanan dan di sebuah universitas swasta di Tangerang. Ia dengan tegas menyatakan bahwa ia menginginkan anak perempuannya terus bersekolah ke jenjang perguruan tinggi setelah lulus SMA. Dia tidak mengkawatirkan tentang julukan perawan tua yang mungkin akan dilekatkan kepada anaknya. Menurutnya, julukan itu hanya berlaku bagi para perempuan yang menganggur dan tidak punya kegiatan lain selain menunggu pria untuk melamarnya.

Lebih lanjut ia menyatakan bahwa saat ini perempuan harus mampu bekerja dan tidak selalu bergantung pada suami, bahkan responden sempat menyinggung istilah kesetaraan gender. Saat digali lebih lanjut, ditemukan bahwa ia mendapatkan informasi mengenai hal ini saat ia mengikuti pelatihan dalam sebuah program pemberdayaan perempuan desa yang dilaksanakan di kota kecamatan. Transfer informasi terbukti mampu memberikan pandangan-pandangan baru bagi para perempuan desa yang dapat mereka terapkan kepada diri mereka sendiri dan anggota keluarga yang mereka miliki. Suami responden ini juga sempat diwawancarai oleh peneliti, dan ia menyatakan hal yang identik bahwa ia membebaskan anaknya untuk mencari pengalaman hidup dan sedapat mungkin membekalinya dengan pendidikan yang setinggi-tingginya. Salah satu kutipan hasil wawancara dengan responden tersebut adalah sebagaimana berikut.

"Jaman sekarang, anak lelaki atau perempuan sama pentingnya untuk disekolahin. Biar bisa lebih baik dari orangtuanya. Ya.. siapa tahu anak saya bisa seperti Teteh, sampai S2.” (Bapak K, 49 tahun)

Bapak $\mathrm{K}$ adalah seorang tokoh pemerintahan desa dan pernah tinggal di Tangerang sebagai montir bengkel selama hampir 10 tahun sebelum akhirnya kembali ke desa. Bapak K adalah penduduk asli Desa Neglasari, sementara istrinya (Ibu S, 45 tahun) berasal dari sebuah wilayah di pinggiran Kabupaten Tangerang.

Pendapat Bapak K dan Ibu S jauh berbeda dengan pendapat orangtua A (responden berusia 17 tahun). Orangtua A yang seorang kiai di desa menyatakan kepada A bahwa ia menginginkan anaknya segera menikah setelah lulus. Bahkan dengan eksplisit ia mengatakan kepada A bahwa ia sengaja mengirimkan A ke pesantren luar desa untuk memperoleh calon suami. Alasan ayahnya untuk segera menikahkan dia adalah bahwa untuk menghindari fitnah.

Apa yang disampaikan oleh orangtua A identik dengan ucapan seorang responden lelaki lain yang menghabiskan sebagian besar waktunya di desa dan hanya sedikit melakukan gerak ke luar desa, meski dengan alasan yang berbeda. Dia menyatakan bahwa ia menikahkan anak-anak perempuannya di usia muda karena memang sudah sepantasnya anak-anak perempuan tersebut menikah pada usia tersebut. Selain itu, dia juga menyatakan bahwa ia tidak punya cukup uang untuk menyekolahkan mereka ke jenjang yang lebih tinggi setelah SMP dan kalaupun ada ia akan memprioritaskan pendidikan anak lelakinya. Menurutnya, anak perempuan pada akhirnya akan ikut suaminya sehingga jika memang tidak ada cukup biaya, tidak perlu memaksakan diri bersekolah terlalu tinggi. Saat peneliti mengkonfirmasi dengan menanyakan apa pendapatnya mengenai peneliti yang saat ini sedang menempuh pendidikan lanjutan, responden menyatakan:

"Kalau Teteh kan beda sama para perempuan di sini. Lagipula Teteh punya biayanya.” (Bapak J, 61 tahun)

Apa yang ia maksud dengan "perbedaan" adalah bahwa ia tidak yakin ada perempuan di desa ini yang mau dan mampu untuk bersekolah selama itu. Pandangan tentang hal inilah yang akhirnya mempengaruhi usia kawin si anak perempuan.

Selain dimiliki oleh orangtua, pandangan ini dimiliki pula oleh sang perempuan yang akan atau sudah menikah di usia muda. Para perempuan yang menikah muda umumnya memiliki pandangan yang identik, bahwa 
perempuan tidak perlu membekali diri dengan macammacam pengalaman hidup karena pada akhirnya akan ikut suami. Usia kawin pada akhirnya akan berpengaruh pada actual fertility di mana para perempuan dengan usia kawin lebih muda memiliki kemungkinan lebih besar untuk memiliki actual fertility yang lebih tinggi dibandingkan para perempuan dengan usia kawin yang lebih tua.

Dalam kaitannya dengan penggunaan kontrasepsi, sebagian responden menganggap bahwa penggunaan kontrasepsi adalah "berdosa" dan dilarang oleh agama. Pandangan ini ditemukan pada beberapa responden yang berusia di atas 55 tahun. Namun, saat ini pandangan tersebut hanya dimiliki oleh sebagian kecil responden. Responden umumnya menegosiasikan nilai tentang larangan kontrasepsi dengan nilai larangan menelantarkan anak. Pada upaya negosiasi ini, saat kemudian mereka menginternalisasi nilai bahwa menelantarkan anak lebih berdosa dibandingkan menggunakan kontrasepsi, mereka akan berani mengambil keputusan menggunakan kontrasepsi.

Hal lain yang kemudian mungkin terjadi adalah bahwa sang suami telah menginternalisasi nilai yang sama sehingga kemudian sang istri menggunakan kontrasepsi, atau sang suami masih menginternalisasi nilai bahwa apapun alasannya, penggunaan kontrasepsi tetap salah sehingga ia melarang sang istri menggunakan kontrasepsi. Pada sebagian besar kasus tersebut, sang istri menuruti kemauan suami untuk tidak menggunakan kontrasepsi. Namun terdapat sebuah kasus di mana sang istri melakukan kontrasepsi secara sembunyi-sembunyi tanpa sepengetahuan suami karena pandangan yang berbeda tersebut.

Nilai-nilai di level komunitas yang dipahami oleh individu sangat mempengaruhi keputusan individu untuk menggunakan kontrasepsi atau tidak. Jika mereka memiliki pandangan yang kaku mengenai "haramnya" penggunaan kontrasepsi, pada saat mereka memiliki desired fertility yang sebenarnya rendah, mereka tetap tidak akan menggunakan kontrasepsi sehingga actual fertility mereka tetap tinggi (atau mendekati jumlah anak potensial mereka).

\section{Ruang Gerak Perempuan dalam Pengambilan Keputusandan Fertilitas Aktual}

Dalam bekerja mempengaruhi fertilitas, ruang gerak perempuan dalam pengambilan keputusan bekerja melalui proximate determinant penggunaan kontrasepsi. Para responden perempuan dengan ruang gerak yang lebih luas dalam pengambilan keputusan memiliki kepercayaan diri yang lebih tinggi untuk mengambil keputusan dalam penggunaan kontrasepsi. Merujuk pada lima pola pengambilan keputusan Sajogyo (1983), pengambilan keputusan penggunaan kontrasepsi pada para perempuan ini adalah pengambilan keputusan bersama setara dan bersama dengan istri dominan, bahkan pada satu kasus terlihat bahwa keputusan penggunaan kontrasepsi menjadi keputusan istri sendiri. Sementara pada perempuan dengan ruang gerak dalam pengambilan keputusan yang lebih sempit, keputusan penggunaan kontrasepsi termasuk ke dalam pola pengambilan keputusan bersama dengan suami dominan dan keputusan suami sendiri.

Berdasarkan kelima pola pengambilan keputusan tersebut, perempuan dengan desired fertility tertentu, akan lebih mudah mengontrol penggunaan kontrasepsi saat dia berada di dalam pola pengambilan keputusan istri sendiri, bersama setara atau bersama dengan istri dominan. Sementara pada perempuan yang mana keputusan penggunaan kontrasepsinya berada di dalam pola keputusan suami sendiri atau bersama dengan suami dominan akan lebih sulit untuk mengontrol penggunaan kontrasepsinya, meskipun ia memiliki desired fertility yang rendah. Pada gilirannya, para responden perempuan pengguna kontrasepsi memiliki actual fertility yang lebih sedikit dibandingkan para responden yang bukan pengguna kontrasepsi.

\section{KESIMPULAN}

Berdasarkan uraian sebelumnya, maka ditarik kesimpulan sebagai berikut:

1. Meskipun norma-norma di level komunitas yang lekat dengan Islam konservatif melekatkan perempuan hanya pada fungsi reproduksinya, tetapi di desa studi ditemukan relasi gender yang cukup bervariasi dilihat dari lima aspek otonomi dan kuasa perempuan dalam relasinya dengan lelaki (suami). Terdapat perempuan-perempuan dengan otonomi dan kuasa yang sempit dan ditemukan perempuanperempuan dengan otonomi dan kuasa yang luas. Hal ini menunjukkan sudah mulai ada gejala perubahan sosial dalam komunitas tersebut yang disebabkan oleh pengaruh dari luar, di mana ditemukan responden (perempuan dan laki-laki) yang berasal dari luar desa atau pernah bekerja di luar desa memiliki pandangan yang lebih fleksibel mengenai relasi gender.

2. Hal pada poin satu tersebut menunjukkan bahwa dalam memahami relasi gender, peran lelaki penting untuk diperhatikan sehingga diperoleh pemahaman yang menyeluruh mengenai relasi antara suami dan istri. Dalam hal fertilitas, upaya memahami peran lelaki dapat dilakukan dengan memperhatikan apakah mereka memiliki pemahaman mengenai kepentingan pembatasan kelahiran demi kesehatan istri dan kualitas hidup anak. Di desa studi, istri yang memiliki suami dengan nilai dan pemahaman yang sama terhadap pentingnya pembatasan fertilitas, ditemukan memiliki desired dan actual fertility yang lebih rendah.

3. Di desa studi, penggunaan kontrasepsi terlihat lebih berpengaruh dalam menurunkan actual fertility dibandingkan usia kawin. Penggunaan kontrasepsi sangat dipengaruhi oleh desired fertility, karena hanya dengan memiliki desired fertility tertentu, para perempuan tersebut akan dapat mengambil keputusan menggunakan kontrasepsi di saat ia sudah mencapai desired fertilitynya.

4. Desired fertility seorang perempuan di desa studi terlihat sangat bergantung pada keleluasaannya 
dalam bergerak. Semakin leluasa ia bergerak, semakin banyak transfer informasi yang dia alami dan semakin terbuka pengetahuannya mengenai pentingnya kualitas hidup anak, alih-alih hanya kuantitasnya. Namun demikian, sampai batas tertentu pada perempuan yang terbatas geraknya, terdapat pula pergeseran pandangan mengenai jumlah anak. Semakin leluasa seorang perempuan bergerak, maka semakin rendah desired fertilitynya.

5. Dikaitkan dengan lima aspek otonomi dan kuasa perempuan, penggunaan kontrasepsi terlihat dipengaruhi oleh kelimanya secara bersama-sama; kuasa perempuan dalam pengambilan keputusan ekonomi rumah tangga, kuasa perempuan dalam pengambilan keputusan ukuran keluarga, kebebasan bergerak, sikap gender di level komunitas yang dipahami oleh individu dan ruang gerak dalam pengambilan keputusan. Semakin tinggi kelima aspek tersebut maka semakin tinggi pula penggunaan kontrasepsinya dan semakin rendah actual fertilitynya.

\section{SARAN}

Dari simpulan-simpulan tersebut, lalu ditarik kesimpulan utama penelitian ini yakni, meskipun nilainilai di level komunitas menyarankan anak dalam jumlah yang banyak, tetapi variasi otonomi dan kuasa perempuan di desa studi menghasilkan actual fertility yang berbeda antar individu responden. Di desa studi, hal ini bekerja dengan cara berikut, semakin tinggi aspek otonomi dan kuasa perempuan (terutama aspek kebebasan dalam bergerak), semakin rendah desired fertilitynya. Lalu di antara perempuan dengan desired fertility rendah tersebut, perempuan-perempuan dengan otonomi dan kuasa yang tinggi akan lebih leluasa mengambil keputusan atas pengunaan kontrasepsi sehingga actual fertilitynya semakin rendah. Dalam proses tersebut, upaya memahami otonomi dan kuasa perempuan juga harus dengan memperhatikan peran lelaki, memahami apakah ia menjadi pendukung atau penghambat istri dalam upaya pembatasan kelahiran.

\section{DAFTAR PUSTAKA}

Aggarwal, R. 2006., Exploring the Links Between Environmental Degradation, poverty, And Fertility Among Rural Households: Some Conceptual Issues. Dalam Population-Environment Research Network Cyberseminar on Rural Household Micro-Demographics, Livelihoods and the Environment, $\quad$ April 2006. http://www.populationenvironmentresearch.org/se minars.jsp

Bappenas (Badan Perencanaan Pembangunan Nasional). Tidak Ada Tahun. Tingkat Pengangguran Terbuka Pemuda Menurut Jenis Kelamin dan Wilayah Perkotaan/Pedesaan per Propinsi. http://kppo.bappenas.go.id/files/-4-

Tingkat $\% 20$ Pengangguran $\% 20$ Terbuka $\% 20$ Pemud a $\% 20$ Menurut $\% 20$ Jenis $\% 20$ Kelamin $\% 20$ dan $\% 20$
Wilayah\%20Perkotaan-

Pedesaan\%20per\%20Propinsi.pdf

Baschieri, A. dan A. Hinde. 2007. The Proximate Determinants of Fertility and Birth Intervals in Egypt: An Application of Calendar Data. Dalam Demographic Research. Volume 16, Article 3, Pages 59-96. 30 January 2007. http://www.demographicresearch.org/Volumes/Vol16/3/DOI: 10.4054/DemRes.2007.16.3

Basya, M.H. 2003. Epistemologi Syariat yang Berkeadilan Gender, Sebuah Dekonstruksi Terhadap Fundamentalisme. Dalam Jurnal PerempuanNo. 31, 2003. Yayasan Jurnal Perempuan. Jakarta.

Bongaarts, J. 1978. A Framework for Analyzing the Proximate Determinants of Fertility. Dalam Population and Development Review, Volume 4, Issue 1 (Mar., 1978), 105-132. http://links.jstor.org/sici?sici=0098-

7921\%28197803\%294\%3Al\%3CI05\%3AAFF A TP\%3E2.0.CO\%3B2-V

BPS (Badan Pusat Statistik) dan Macro International. 2008. Indonesia Demographic and Health Survey 2007. Calverton, Maryland, USA: BPS and Macro International.

Easterlin, R.A. 1975. The Effect of Modernization on Family Reproductive Behaviour. Dalam: The Population Debate: Dimensions and Perspectives. Papers of the World Population Conference. Bucharest, 1974. Volume II. Population Studies No.57. Department of Economic and Social Affairs, United Nations: New York.

Guengant, J.P. Tidak Ada Tahun. The Proximate Determinants during the Fertility Transition. Institut de Recherche pour le Développement (IRD).

Hakim, A., S. Salway, dan Z. Mumtaz. 2003. Women's Autonomy and Uptake of Contraception in Pakistan. Dalam: Asia-Pacific Population Journal. Vol. 18, No. 1, March 2003. United Nations.

Hull, V. J. 1975. Fertility, Socioeconomic Status, and the Position of Women in a Javanese Village. Desertasi Doktor. Australian National University. Australia.

Kabir, M.A., M.M.H. Khan, M. Kabir, Mohd. M. Rahman dan MD. Fazlul Karim Patwary. Tidak ada tahun. Impact of Woman's Status on Fertility and Contraceptive Use in Bangladesh: Evidence from Bangladesh Demographic and Health Survey, 1999-2000.

Mahmoudian, H. 2005. Fertility Decline and Change in Women's Status in Iran. Makalah yang dipresentasikan pada the International Union for the Scientific Study of Population XXV 
International Population Conference, Tours, Prancis, 18-23 Juli, 2005

Mason, K.O. dan H.L. Smith. 1999. Female Autonomy and Fertility in Five Asian Countries. Washington, DC: the World Bank dan Philadelpia: University of Pennsylvania.

2003. Women's Empowerment and Social Context: Results From Five Asian Countries. Washington, DC: the World Bank dan Philadelpia: University of Pennsylvania

Moses, L. Y. A., dan J. B. Kayizzi. 2007. Using the Bongaarts model in explaining fertility decline in Urban areas of Uganda. A paper to be presented during the Fifth African Population Conference: Arusha 10-14 December 2007. Session "Emerging issues in the Demography of East Africa"

Nataprawira, I. dan A. Pribadi. 2003. Fundamentalisme Islam dan Persoalan Perempuan. Dalam Jurnal Perempuan no.31, 2003. Yayasan Jurnal Perempuan. Jakarta.

Randall, S. dan T. Koppenhaver. 2004. Qualitative Data in Demography: The Sound of Silence and Other Problems. Dalam Demographic Research. Volume 11, Article 3. 26 August 2004. www.demographicresearch.org

Riley, N.E. 1997. Gender, Power, and Population Change. Dalam: Population Bulletin Vol. 52, No. 1, Mei 1997.

Robinson, W.C., dan S.F. Harbinson. 1983. Menuju Teori Fertilitas Terpadu. Yogyakarta: Pusat Penelitian dan Studi Kependudukan Universitas Gajah Mada.

Sajogyo, P. 1983. Peranan Wanita dalam Perkembangan Masyarakat Desa. Jakarta: Yayasan Ilmu-ilmu Sosial (YIIS)

Savitri, L. 2007. Uncover the Concealed Link: Gender \& Ethnicity Divided Local Knowledge in the AgroEcosystem of a Forest Margin: the Case Study of Kulawi and Palolo Local Knowledge in Central Sulawesi. Desertasi Doktor. Unikassel Versitat: Jerman.

United Nations Statistics Division. 2011. Social Indicators: Table 1c Population Growth and Distributions.

http://unstats.un.org/unsd/demographic/products/s ocind/default.htm 